\title{
25 Years of Curating Digital Art: 1993-2018
}

\author{
Bruce Wands \\ Artist, Writer, Musician \& Curator \\ Chair Emeritus, MFA Computer Arts \\ School of Visual Arts, New York, NY, USA \\ bwands@sva.edu
}

\begin{abstract}
As digital art merges with contemporary art, there have been many fundamental changes in the creative process. New forms of art continue to emerge and a revolutionary change in the art experience is occurring in museums, galleries and on the Internet. As a digital art curator, I have been fortunate to be a part of this revolution and will share my experiences and thoughts about past, present and future developments in curating traditional, contemporary and digital art. After a few landmark exhibitions in the late 1960s, digital art found an early home in international organisations, such as Ars Electronica, ISEA, New York Digital Salon, and ZKM. The development of the World Wide Web in the mid-1990s gave digital art the additional exposure it needed. Artists could now sidestep the traditional art establishment and reach a global audience through their websites. The Internet also expanded the art experience beyond galleries and museums into homes, schools and portable devices. 2001 joined 1968 as a landmark year for major museum exposure of digital art with BitStreams and Data Dynamics at the Whitney Museum of American Art and 010101 at the San Francisco Museum of Modern Art. What transpired over these decades has reshaped contemporary art and presented new challenges to museum professionals faced with this new art form. When looking towards the future, we will see a continued merging of digital art with contemporary art. New ways of exhibiting and creative self-expression using VR and Augmented Reality, along with other new, yet to be invented, technologies will be developed as they continue to infuse our daily lives and art experiences. This paper will examine the evolution of curating digital art over the past twenty-five years.
\end{abstract}

Art history. Curating digital art. Ars Electronica. ISEA. Lumen Prize. New York Digital Salon. V2_ZKM.

\section{INTRODUCTION}

Having roots in the 1960s, digital art was originally looked at as Outsider Art. It did not fit into the traditional fine art categories of drawing, painting and sculpture. It found an early home in international organisations, such as Ars Electronica, ISEA, New York Digital Salon and ZKM, which were dedicated to promoting this new art form. While there were two landmark exhibitions in 1968, Cybernetic Serendipity at the ICA in London and The Machine as Seen at the End of the Mechanical Age at MoMA in New York City, digital art failed to gain momentum until the 1980s spawned a widespread proliferation of personal computing and technology and made it practical for artists. As the field expanded, it was the development of the World Wide Web in the mid1990s that gave digital art the global exposure it needed. Artists could now sidestep the traditional art establishment and reach a multicultural audience through their websites. The genre of Net Art emerged out of rapid developments in browser software and artists like JODI, who used the
Internet as their primary medium, brought attention to new forms of creativity. The Internet also expanded the art experience beyond galleries and museums into homes, schools and portable devices.

2001 joined 1968 as a landmark year for major museum exposure of digital art with BitStreams and Data Dynamics at the Whitney Museum of American Art and 010101 at the San Francisco Museum of Modern Art. Both exhibitions explored the influence technology was having on art making and presented a variety of works using the full spectrum of digital media. 2018 marks the 50th anniversary of those exhibitions. What transpired over these decades is reshaping contemporary art and the digital art exhibitions held since then reveal the challenges museum professionals are facing in adapting to this new art form and technology.

When looking towards the future, we will see a continued merging of digital art with contemporary art. The new generation of emerging artists has grown up in a digital world and does not know of 
the traditional barriers that used to exist for digital art. New forms of art using VR and Augmented Reality along with other new technologies will be developed as they continue to infuse our daily lives and art experiences.

\section{CURATING TRENDS AT THE TURN OF THE MILLENNIUM}

The landmark exhibitions and events during the late 1960s were one-time events that set the stage and created an environment for the emergence of digital art into the traditional art world. At the time, and for the next few decades, digital art was considered as Outsider Art and museums and galleries were hesitant to embrace this form of creative self-expression. This prompted the establishment of digital art organisations that were involved with the promotion, exposure ad nurturing of art made with technology. Some of the early key organisations were Ars Electronic, ISEA, New York Digital Salon, V2 a and ZKM. While it is hard to believe, in light of where we are now, there was a time in the not too distant past when museums and galleries did not have websites. The first wave of museum and gallery websites consisted of images and text. Computers at that time had a limited colour palette, which consisted of 256 colours that would work well on Internet browsers. It was not until 2011 that the True Color 24 bit palette became widely used and enabled 16.7 million colours to be displayed.

The next development in the web-based exhibition of art was streaming technology. This began with audio and was followed by low-resolution video and now the HD video we enjoy today. The key factor in enabling streaming audio and video is bandwidth. Early access to the Internet for the average person was limited to 56 kilobits per second and has continue to increase dramatically to the point where gigabit Internet is now available to the average user, although still quite expensive.

Given these developments, how has this technology affected curators? Within the infrastructure of a museum, most of the developments using the Internet were related to a more informational role at first. For example, instead of having a text only and an image-based website, streaming audio and video enabled museums to broadcast interviews and show videos over the Internet. Internally, curators now had increased capabilities, with the advent of wireless technology for audio tours of exhibitions and interactive exhibits. While these followed the development of video art and also made the museum experience richer via interactive information kiosks, art created with technology, which were part of the museums' collections, also began to appear in exhibitions.

This is one area in which digital organisations excelled during the early period of curating digital art. Since museums were slow to embrace this art form, there was a dearth of museum curators who were involved with and knowledgeable about this new art. These curators often found their place in organisations like ARS Electronica, New York Digital Salon, ZKM and other groups that had annual or traveling exhibitions. Began as an annual festival in 1979, Ars Electronica established the international Prix Ars Electronica competition in 1987. In 1996, they established the Ars Electronic Center, which provided year-round facilities for the production and presentation of digital and new media art. This centre was integrated with their other activities in 2009 to provide a comprehensive approach with four elements-the Festival, the Prix, the Center and the Futurelab. Their website contains an archive dating back to1987 of the Prix Ars Electronica Showcase and a print archive since 1979, which allows visitors to view and search artist submissions and writings.

ZKM was established in 1984 with the idea of creating an institution uniting artistic concepts with future-oriented technologies. Like Ars Electronica, it expanded in 1997, opening the doors of the restored Hallenbau, and presented its institutes, departments and extensive exhibition, concert, and event spaces to the public as the ZKM | Media Museum, the ZKM | Museum of Contemporary Art, as well as the Institute for Visual Media, Institute for Music and Acoustics, the Media Library, the Media Theatre and the Blue Cube.

Other digital and contemporary art organisations included the V2_Lab for the Unstable Media, which is an interdisciplinary centre for art and media technology in Rotterdam. V2_ presents, produces, archives and publishes research at the interface of art, technology and society. Founded in 1981, it offers a platform for artists, designers, scientists, researchers, theorists, and developers of software and hardware from various disciplines to discuss their work and share their findings. Founded in the Netherlands in 1990, ISEA International (formerly the Inter-Society for the Electronic Arts) is an international non-profit organisation fostering interdisciplinary academic discourse and exchange among culturally diverse groups and individuals working with art, science and technology. The main activity of ISEA International is the annual International Symposium on Electronic Art (ISEA). The New Museum, founded in 1977, was the first museum devoted to contemporary art in New York City since the Second World War, and the New York Digital Salon began in 1993. 


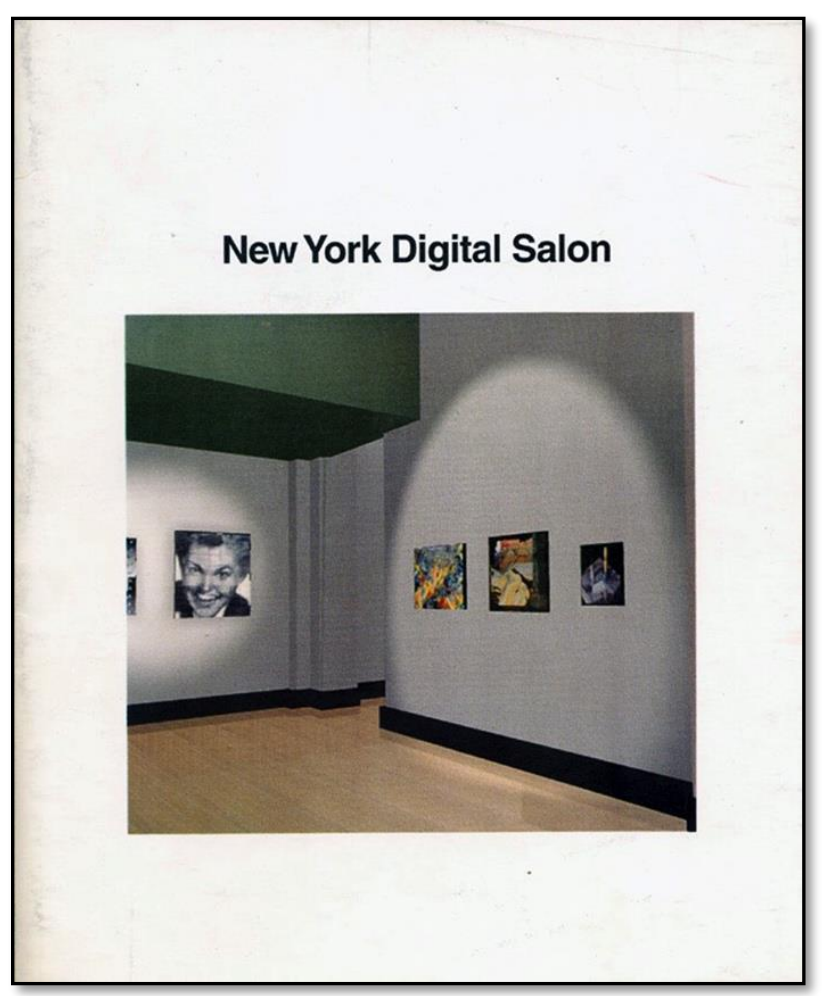

Figure 1: Cover of the $1^{\text {st }}$ New York Digital Salon catalogue. The exhibition was curated using 3D software to create a virtual reality space of the New York Art Directors Club venue.

As the Curator for the first three New York Digital Salon exhibitions and the Director from 1998-2017, the author moulded this organisation from an annual exhibition in New York City into an international touring program that encompasses exhibitions, symposia and panel discussions with digital artists, various educational and public events, and an online resource www.nydigitalsalon.org. While many of the European organizations had the benefit of government funding, the New York Digital Salon was primarily funded by the School of Visual Arts MFA Computer Art program, grants from non-profit organisations including the Rockefeller Foundation, National Endowment for the Arts (NEA) and the New York State Council on the Arts (NYSCA) and private corporations. The NYDS began traveling internationally in 1998 to the Circulo des Bellas Artes in Madrid. It had several venues in Europe between 1999 and 2002 including Barcelona, Gijon, Malaga, and Valladolid, Spain, Milan, Italy, Portugal, Beijing, China and Korea. For the 10th anniversary in 2003, the Rockefeller Foundation helped support a Digital Art Symposium, which brought together over 30 digital art curators, artists, and art historians. Videos of this conference and other panels are available online (http://www.nydigitalsalon.org).

Over the past ten years, both the traditional digital art organisations and new venues, such as The
Lumen Prize, have continued to support this art form. Museums and galleries are now including digital art as a component of contemporary art and the black and white of digital art as Outsider Art and what is now contemporary art is quickly becoming many shades of grey. The divisions that once existed are no longer apparent and museums and galleries are now supporting and have become committed with both new media curators and technology to support and exhibit this creative work.

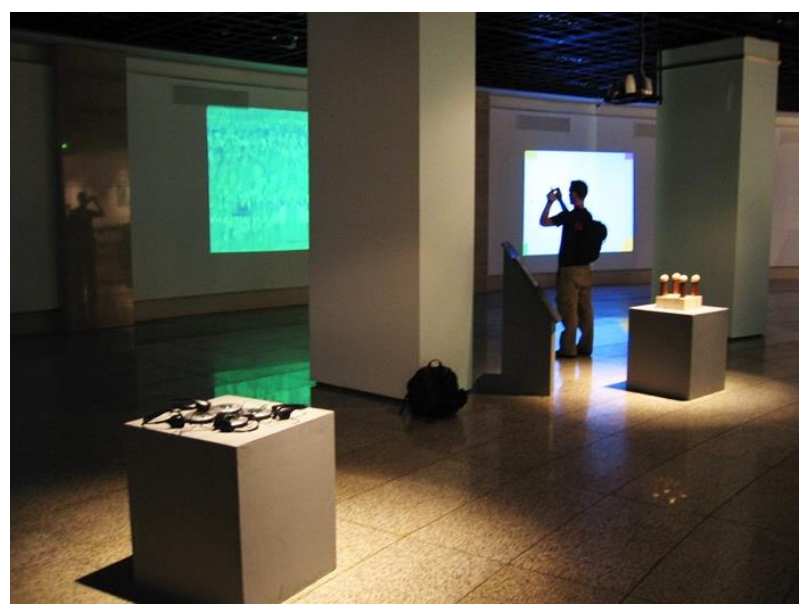

Figure 2: New York Digital Salon at the First Beijing International New Media Arts Exhibition, Millennium Museum, 2004. There was no shipping budget and the mandate was to bring what you could fit into a suitcase. Two small video projectors showing images and video, along with $C D$ players for sound art and a small-scale version of the interactive music installation, Variations by Bruce Wands were exhibited.

\section{THE FUTURE OF CURATING}

When looking towards the future, curating, creative self-expression and art exhibitions will continue to change with technological and software developments. The use of the Internet for curating and documenting exhibitions has been accepted. Virtual reality galleries and museums are the new leading edge for exhibiting art. There are also new systems for juried shows, which include database systems for artists enter competitions and group shows. The databases generally consist of the artist's name, bio, work they want considered, artist statement, and the art or documentation URL. Systems like these allow curators or jury members to evaluate the work and my experience has been that the work is narrowed down to the final selections in several stages. Jury members also have the option to add comments about the work. Ultimately, the final selections will end up in a website that is formatted, designed and made available to the general public. Another aspect of this process is a new model of curating and exhibiting digital work. Given the wide range and complexity of work that is considered, some 
competitions and exhibitions have built in a more flexible approach to the work that exists on the website and is included in the exhibitions held in different venues. In a typical museum exhibition, there is a finite gallery space and budget established before the exhibition is curated and designed. For traveling exhibitions, the venues and budgets vary and an online list of works also allows for local curators and venues to custom tailor the exhibition to suit their needs.

This was done for the $10^{\text {th }}$ New York Digital Salon exhibition in 2003. The premise of the anniversary celebration was to have new media curators select the 100 most significant digital art works and have them published on a website and in a special issue of Leonardo, Journal of the International Society for the Arts, Sciences and Technology published by the MIT Press. The logistics and cost of mounting such an exhibition was formidable, and we decided to let the different venues select the work they wanted to include in their exhibitions. While there was some criticism from the artists, as this was a new curatorial model, the new approach ended up working well. The idea of having the selected works on a website and mounting exhibitions depending on the venues' needs and budget is also used by The Lumen Prize. It is the opinion of the author that this new model for curating digital art takes advantage of both the capabilities of the Internet and makes the exhibitions much more adaptable for the venues.

One logical extension of this idea is to bypass the venues altogether and use virtual reality and the Internet as the complete venue. Virtual reality technology, while still developing and somewhat difficult and expensive to implement is already being used in this way. The Frick Collection in New York City houses masterpieces of Western painting, sculpture, and decorative art. The museum offers a virtual tour of galleries that visitors can navigate in a nearly photorealistic fashion. The website also has images of the works, videos, archives and the facility contains a Digital Art History Lab. It is a superb example of how a museum is taking advantage of the Internet, virtual reality and today's software and technology to enhance the art and museum experience. While not a substitute for the actual experience of visiting the collection, it offers to those not able to do so an all-encompassing experience. The Louvre Museum in Paris offers a similar experience. Many other museums are moving in this direction and some are even totally virtual, without a physical location at all.

This brings up questions regarding the experience of art in a virtual versus physical way. While this discussion is beyond the scope of this paper, it will be one that will occupy many art historians, curator and scholars for years to come. How important is it to be physically present in a museum? How will the younger generation value physical versus virtual presence? Only time will tell. Finally, the creation of virtual reality art is also a rapidly growing area of interest for artists. Most of this work is not Internet oriented, but relies on wearable headsets for the viewer to experience the art. Having roots in the early work of Char Davies, the creative possibilities have expanded greatly over the past twenty years. Virtual reality and augmented reality artwork takes on many hybrid forms. There are works that completely rely on the headset and other works that use augmented reality that combines art with the real world through the use of video and overlaid images and animation. There is the software Tilt Brush, which allows the artist wearing a headset to paint in a 3D virtual space. As these new technologies emerge, artists will continue to keep pace with them and discover creative uses for them.

\section{CONCLUSION}

The above has been a brief glimpse into the changes and impact new technology has had on creativity, art making and the curation and exhibition of contemporary art. In a relatively brief timespan, software and technology have fundamentally changed this process. The future looks promising. The idea of a virtual gallery for the $1^{\text {st }}$ New York Digital Salon in 1993 was hampered by inadequate technology. Now that we have more advanced 3D software and increased bandwidth, this idea has come to fruition in museums such as the Frick Collection, Louvre Museum and a growing list of others. Artists will help redefine the gallery space of the future. Continuing issues needing attention will be archiving and software emulation of art created as objects and as software systems. The largest benefit will be the democratization and expansion of the art experience on a global, multicultural level through new media.

\section{REFERENCES}

Archive of Digital Art. https://www.digitalartarchive.at/database/databaseinfo/archive.html (retrieved 29 March 2018).

Ars Electronica. https://www.aec.at/news (retrieved 29 March 2018).

Art of the Digital Age. http://artofthedigitalage.com/ (retrieved 29 March 2018).

Blais, J., and Ippolito, J. (2006) At the Edge of Art. Thames \& Hudson, New York.

Digital Art Museum. http://dam.org/home (retrieved 29 March 2018). 
Frick Collection. https://www.frick.org/ (retrieved 29 March 2018).

Graham, B., and Cook, S. (2010) Rethinking Curating. MIT Press, Cambridge, MA.

Grau, O. (2007) Media Art Histories. MIT Press, Cambridge, MA.

ISEA International. http://www.isea-web.org (retrieved 29 March 2018).

Leonardo Online Archive 1968-2017. https://muse.jhu.edu/journal/116 (retrieved 29 March 2018).

Louvre Museum.

https://www.youvisit.com/tour/louvremuseum (retrieved 29 March 2018).

Lumen Prize. https://lumenprize.com/ (retrieved 29 March 2018).

Malloy, J. (ed.) (2003) Women, Art, and Technology. MIT Press, Cambridge, MA.

Mongeon, B. (2016) 3D Technology in Fine Art and Craft: Exploring 3D Printing, Scanning, Sculpting and Milling. Focal Press, Burlington, MA.

New Museum Digital Archive.

http://archive.newmuseum.org (retrieved 29 March 2018).

New York Digital Salon.

http://www.nydigitalsalon.org (retrieved 29 March 2018).

Packer, R., Jordan, J. (eds.) (2001) Multimedia: From Wagner to Virtual Reality. W. W. Norton \& Company, New York.
Paul, C. (2015) Digital Art, Thames \& Hudson, London, UK.

Paul, C. (2008) New Media in the White Cube and Beyond: Curatorial Models for Digital Art. University of California Press.

Rhizome ArtBase. http://rhizome.org/art/artbase (retrieved 29 March 2018).

Shanken, E. (2009) Art and Electronic Media. Phaidon Press, London, UK.

SIGGRAPH Digital Arts Community.

http://siggrapharts.ning.com (retrieved 29 March 2018).

V2_, Lab for the Unstable Media.

http://v2.nl/organization (retrieved 29 March 2018).

Victoria \& Albert Museum (Computer Art Page). http://www.vam.ac.uk/content/journals/researchjournal/issue-02/computer-art-at-the-v-and-a (retrieved 29 March 2018).

Weibel, P., Druckrey, T. (eds.) (2001) net_condition: Art and Global Media. MIT Press, Cambridge, MA.

Wands, B. (2006) Art of the Digital Age. Thames \& Hudson, London, UK.

Wilson, S. (2002) Information Arts. MIT Press, Cambridge, MA.

Wilson, S. (2013) Art + Science Now. Thames \& Hudson, New York.

ZKM. http://on1.zkm.de/zkm (retrieved 29 March 2018). 